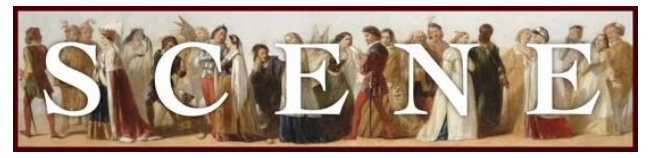

\title{
Shakespeare, Lord of Love and Changes
}

by Prabhjot Parmar and Melissa Walter. Written on 2017-09-28. Published in 2017 Issue 2.

For the production: Piya Behrupiya "The Beloved Imposter" (2016, The Company Theatre, Canada). See production details at the end of the review.

Piya Behrupiya, or the "Beloved Imposter," played at the Cultch's York Theatre in East Vancouver from Oct 11-22, 2016 as part of Diwali fest. Translated by Amitosh Nagpal and directed by Atul Kumar from Mumbai's The Company, Piya Behrupiya was originally commissioned by London's Globe Theatre for its 2012 Globe to Globe festival, which required that performances could not be in English. A colorful tapestry of Hindi and Urdu with occasional use of English and Punjabi, the play combines nautanki folk theatre (from Uttar Pradesh, a northern state) with Shakespeare's Twelfth Night. The Company "work[s] with an inter-disciplinary \& multi-cultural approach to diverse art forms, rooted in a search for the truth of human experience." Their play continues to tour globally and is available on video through Netflix. It offers energetic music, dance, and clowning along with poignant moments of yearning and compassion, inviting the audience into a transnational space that warmly embraced Shakespeare, Twelfth Night, and love in all their changes.

On this windy October night in southwestern British Columbia, the music (provided by the harmonium of Amod Bhatt, the dholak of Rahul Sharma, and percussion accompaniment by Niketa Saraf) was set up on a raised platform at the back of the stage-a quintessential component of nautanki. Four gilded columns lent a sense of occasion. The cloth backdrop for the action bore a large image of Shakespeare (Chandos-portrait-like) wearing a mukut (crown), and placed above a pink lotus, in a style evoking the calendar art of Raja Ravi Verma.[1] In this portrayal, the peacock feathers on the mukut and the blue tint to Shakespeare's skin suggest an allusion to Lord Krishna (eighth incarnation of the Hindu God Vishnu, the preserver), master of impersonation (behrupiya) and changes, the "most wily of gods"[2] who also represents compassion, beauty, and love. Shakespeare's artistic representation in a Krishna-like form obviates as well as frames the play's theme of love that drives most of the action. Furthermore, the allusion celebrates the actor and playwright's arts of impersonation and empathy, while also claiming for Shakespeare an almost god-like stature. At the same time, irreverent clowning 
contributed to the picture, as comic characters complained about their position in the script and about the translator "bowing to the genius of Shakespeare." According to director Atul Kumar, the "adaptation is extremely tongue in cheek."[3]

Of course, Shakespeare came to India via colonial education, and his works have become a part of Indian letters; due to the colonial educational apparatus and the postcolonial celebration of "the Bard," they are now as well or better known to many even than the classical Sanskrit author and playwright Kalidasa. In consequence, this production uses the conventions of nautanki form - traveling folk theatre for popular audiences, characterized by a bare stage, music, audience interaction, and clowning. Nautanki plots often retell mythological stories, and the nautanki form frequently appears in classic Bollywood cinema highlighting its centrality as a popular folk medium. The convention's use in Piya Behrupiya has the effect of implicitly claiming Shakespeare for Indian folk culture. [4]

In Canadian diasporic space, the play celebrates Shakespeare's Indianness through both language and form. The performance of Shakespeare in Hindi takes on a new resonance for a largely Punjabi-speaking diaspora in Vancouver, where plays performed in this language are quite rare; to see a nautanki Shakespeare in Vancouver is intriguing and notable. For those audience members familiar with Indian folk theatre, it was as if India had come to them. The symphonic combination of folk music and Hindi-speaking actors from India transformed not only the stage but also the theatre into an Indian space which resounded with the familiar strains of harmonium and rhythmic beats of dholak, and dialogue in different Hindi dialects (interspersed with occasional Punjabi words and inflections).

For some of the Indian diasporans present, the immediate power of theatre and performance obviously created a potent feeling of being in India, albeit without any travel. Almost mirroring the dualities of its lead characters, Piya Behrupiya evoked a shifting transformation between home and the diasporic space within the theatre. To some extent, the experience stripped bare emotional and sensory responses that may, for some, be hidden or disguised behind a more diasporic (in Vancouver) public façade. In so doing, Piya Behrupiya offered geographic comfort by conjuring up domiciliary connections through its onslaught of localized sensory imagery. Meanwhile, many non-Hindi speakers inevitably struggled to read the English translations of the text, projected on either side of the stage, while still taking in the fast-paced stage action and music. Song lyrics were often not translated in full. This said, many contemporary speakers of English find Shakespeare's early modern English opaque, and for some viewers, the subtitles and vivid action made it "easier to understand the events and the zaniness that transpired."[5] The non-Hindi speakers' understanding clearly lagged behind that of many 
audience members in the house, who seemed to understand the language and get all the jokes.[6]

Yet true to the nautanki form, the performance was also very inclusive. [7] Twelfth Night's English title indicates a day of carnivalesque festive inversion, where all are included in the festivity even if, like Malvolio, they think they are not. Here, nautanki performance conventions of clowning and direct engagement with the audience drew us into Piya Behrupia's festive spirit. Sir Andrew (Aadar Malik) and Sir Toby (Gagan Riar) instructed us to wave our hands to the beat. Local touches added humor. At one point, for instance, Sir Toby demanded silence-he was tired and there had been "too much traffic on the Lion's gate bridge." "Andrew! Please be professional," he begged, but to no avail. Instead, Andrew flirted with audience members, drank, and fell off the stage. Meanwhile, Sebastian (Mantra Mugdha), annoyed that he doesn't enter until Act 2, tried to enlist the audience's sympathy because Shakespeare's play had not given him enough prominence. He comically complained that "Shakespeare thought of Sebastian in a dream and added him as an afterthought to tie up the ending," which some might see as astute commentary on the dynamics of twinning and the status of Sebastian as a character in the original narrative.[8]

If this production celebrated the carnivalesque, it did so by highlighting Orsino's famous plea, "If music be the food of love, play on." Indeed, Piya Behrupiya begins with music, including "a song celebrating young love," while other songs accompany transformations and give emotional color throughout the play. [9] Olivia, falling in love with Viola/Cesario (Geetanjali Kulkarni), sings of feelings that evoke pigeons and the scattering of bird seed, lyrics that are reprised towards the end of the play. In describing her feelings for Orsino or plans to woo Olivia ineffectually, Viola/Cesario sings, "there is a door that never opens." In act 2, scene 4, where the play expresses "was not this love indeed," Viola/Cesario stands in a spotlight that creates a sense of isolation, only to take off her head covering, show her hair, and sing an impassioned solo. The whole company then sings along with her, in Hindi, with no subtitles, in a moment of shared longing, poignancy, and emotion. Immediately after, Sebastian enters noisily with a cell phone, breaking the tension.

Music, therefore, gives the play a strong sense of dramatic rhythm, its narrative working like a score in terms of the emotional beats and changes in tone, while also holding the passionate emotion within an upbeat yet philosophical frame. Among the songs of the wise fool (Neha Saraf, gendered female in this play), is "the fool's song for soothing spirits in distress, with lyrics including, "the world laughs as we cry," and a "fool's song of wisdom, declaring that love is blind." The play's final song includes the words, "our desire for worldly things never abates." 
As suggested by Viola's isolated position on the bare stage, a spotlight was used effectively to make intimate moments private and underscored the oscillations between isolation and community, anguish and compassion, grief and laughter that are so central to Twelfth Night. One reviewer noted that, because the off-stage actors waited with the musicians and were always fully visible to the audience, "there was some dramatic irony in that, throughout the play, Sebastian and Viola were in actuality very close to each other the whole time," their proximity seemingly asking how alone we really are?[10]

Along with its reassuring message of community, Piya Behrupiya has a feminine and feminist heart. One reviewer thought that Piya Behrupiya made the silliness of men (evident in Shakespeare's original drama) "almost the main idea," with Sebastian representing the "main example of this - the writers completely made his character into a joke."[11] Although Viola/Cesario's centrality is already evident in Twelfth Night, in Piya Behrupiya, the cleverness and locus of control is more clearly feminine.[12]

At the same time, Viola's transformation into Cesario is necessary in a play whose urban space confirms "the city is no place for a girl to be safe." Piya Behrupiya's cross-dressing also includes, however, a feminist and/or gender-queer perspective. In an early scene between them, Orsino actually has his arms around Cesario and feels her breasts, letting the audience see his surprise and appreciation; this moment interrupts neither the story nor Orsino's use of the male pronoun to refer to Cesario. [13] In the passionate scene between them (2.4) Cesario even slaps Orsino and almost kisses him. Equally passionately in a later scene, Olivia also almost kisses Cesario. Olivia declares, "I wish you were mine, then I wouldn't care who you are." Cesario's response, that "There must be a real problem that [he] cannot" requite that love suggests a political claim for love and self-determination, one that the Cultch audience cheered and applauded, the scene immediately followed by a "devotional song for souls in distress." According to Anna Stelmach, "[w]atching the actors seamlessly transform from spotlight star, to background dancers, to heckling observers themselves, parallels the ease of crossdressing transformation from woman to man. In Piya Behrupiya, you leave with a sense of inclusion: we are all humans and we are all capable of love."[14]

\section{Notes}

[1] Our co-authored review arises out of an extremely generative conversation about the performance. Here Melissa Walter would like specifically to acknowledge Prabhjot Parmar's insights regarding the significance of this production in Canadian diasporic space, the meaning of "Piya Behrupiya," and the similarities of the backdrop to the Raja Ravi Verma's calendar art and the allusion to Lord Krishna. 
[2] In Srinivas Krishna's film Masala (1991), the character of grandmother Tickoo (Zohra Sehgal) refers to Lord Krishna as "the most wily and mischievous of gods."

[3] Quoted in Matt Wade, "High drama, sexual politics, exaggerated poetry": a cheeky Indian take on Shakespeare, The Sydney Morning Herald, September 15 2016, http://www.smh.com.au/entertainment/art-and-design/sydney-arts/high-drama-sexualpolitics-exaggerated-poetry-a-cheeky-indian-take-on-shakespeare-20160913-grfiaz.html.

[4] In this regard, Shormishtha Panja similarly argues that Bagro Basant Hai, an adaptation of $A$ Midsummer Night's Dream by Raghuvir Sahay, which draws on Sanskrit drama and nautanki, is rooted "squarely in the Indian tradition" ("An Indian (Mid)Summer: Bagro Basant Hai," pp. 204216 in India's Shakespeare: Translation, Interpretation, and Performance, ed. Poonam Trivedi and Dennis Barholomeusz, Newark: U of Delaware Press 2005, p. 207). And Sukanta Chaudhuri summarizes by stating that "The Shakespearean presence in India is older and more complex than in any other country outside the West," "Shakespeare in India," http://internetshakespeare.uvic.ca/Library/Criticism/shakespearein/indial/.

[5] Caleb Munro. University of the Fraser Valley students Julia Toews, Emily Eggert-Botkin, Caleb Munro, Anna Stelmach, Chris Shumanon, and Emma Vander Eyk contributed to this review. Direct quotes and specific commentary are acknowledged in text.

[6] This kind of de-centering of English-language audiences was also one of the interesting potential effects of the 2012 Globe to Globe festival—one that is particularly highlighted, for instance, in Two Gents Productions' Shona/English Vakomana Vaviri Ve Zimbabwe.

[7] Julia Toews noted "a sense of inclusiveness that spanned the exclusivity of the cultural and language gap."

[8] Quoted by Emma Vander Eyk. Indeed, Sebastian "poked fun at Shakespeare himself" (Emily Eggert-Botkin).

[9] For Kumar, the music is "really the strong point" of Piha

Beyrupiya. https://www.youtube.com/watch?v=U78Wlz6pK_c.

[10] Chris Shunamon.

[11] Emma Vander Eyk

[12] Vander Eyk

[13] Chris Shumanon.

[14] Anna Stelmach. 


\section{Production Details}

\section{General}

Title

Piya Behrupiya "The Beloved Imposter"

Year

2016

Theater Company The Company Theatre

Theaters

The Clutch - York Theatre (Canada

Start Date

2016-10-11

End Date

2016-10-22

\section{Cast}

\begin{tabular}{|c|c|}
\hline VIOLA & GEETANJALI KULKARNI \\
\hline ORSINO & SAGAR DeShMUKh \\
\hline OliviA & MANSi Multani \\
\hline FEste & NEHA SARAF \\
\hline Тову & GAGAN RIAR \\
\hline ANDREW & AADAR MALIK \\
\hline MARIA & TRUPTI KHAMKAR \\
\hline SEBASTIAN & MANTRA Mugdha \\
\hline MALVOLIO & SAURABH NAYYAR \\
\hline
\end{tabular}

\section{Creatives}

\begin{tabular}{|c|}
\hline DIRECTOR \\
\hline ASSISTANT DIRECTOR \\
\hline DANCE ASSISTANT \\
\hline Costumes \\
\hline Costumes \\
\hline Costumes \\
\hline HARMONIUM \\
\hline Music Assistant \\
\hline Music Assistant \\
\hline PERCUSSION ACCOMPANIMENT \\
\hline Music Assistant \\
\hline DHOLAK \\
\hline DMINISTRATOR \\
\hline RANSLATOR \\
\hline
\end{tabular}

ATUl KumAR

RACHEL D'SOUZA

NeHA SARAF

TRUPTI KHAMKAR

KIYOMI MEHTA

NEHA SARAF

AMOD BHATT

SAURABH NAYYAR

GAGAN RIAR

NiKETA SARAF

RAHUL SHARMA

RAHUL SHARMA

PRIYANSHI BAHADUR

AMITOSH NAGPAL 